УДК: 378.015.31:52

UDC: $378.015 .31: 52$

DOI: $10.31475 /$ ped.dys.2019.27.07

ТЕТЯНА ШЕСТАКОВА,

кандидат педагогічних наук, доцент

(Украӥна, Буча, Український гуланітарний інститут, вул. Інститутська, 14)

TETIANA SHESTAKOVA,

Candidate of Pedagogical Sciences, Associate Professor (Ukraine, Bucha, Ukrainian Humanities Institute,

Institutska str., 14)

ORCID: 0000-0003-1283-8524

\title{
Філософські витоки професійного самовдосконалення учителів початкових класів
}

\section{The Philosophical Origins of Professional Self-Improvement of Primary School Teachers}

У статті на основі глибокого аналізу розвитку ідеї саловдосконалення в історіі фбілософбської дулки виділено й описано ідеалістичне, матеріалістичне та діалектичне розуміння саловдосконалення особистості, подано їх порівняльну характеристику та підкреслено їх значення для фборлування власної світоглядної позицї щодо профбесійного саловдосконалення у вчителів початкових класів. Авторол здійснена спроба класибікувати учителів початкових класів залежно від домінуючих тенденцій у власному профбесійнолу саловдосконаленні на педагогів-ідеалістів, прагматиків $i$ гарлонізаторів. Підкреслюеться важливість ознайомлення майбутніх учителів початкових класів із представленили вище фбілособбськими підходами в розумінні сутності $і$ змісту самовдосконалення особистості.

Ключові слова: профбесійно-педагогічне саловдосконалення, ідеалістичне, матеріалістичне, діалектичне, учитель початкових класів.

Based on a deep analysis of the development of the idea of self-improvement in the history of philosophical thought, the article highlights and describes an idealistic, materialistic and dialectical understanding of self-improvement of a person, presents their comparative characteristics and emphasizes their importance for the formation of a personal worldview position regarding professional self-improvement among primary school teachers.

Idealistic understanding is based on the recognition of the self-improvement of the self as a purely internal activity aimed at the development of spirituality, enriching the inner world of man by actualizing the potential strengths and capabilities. The materialistic approach characterizes selfimprovement as the predominantly external activity of a person aimed at achieving the socially determined and socially conditioned ideal of mental, physical and moral perfection by correcting one's own activity and behavior in accordance with the norms and values of a certain society for self-assertion in it. In a dialectical approach, idealistic and materialistic views on the nature of this phenomenon are harmonized on the basis of the unity of opposites and the primacy of humanistic values, whereby selfimprovement of the individual is interpreted as activity aimed at both the enrichment of the inner world and the perfection of the outside world.

The author made an attempt to classify primary school teachers according to the dominant tendencies of their personal professional self-improvement into idealistic teachers, pragmatists, and harmonizers. The importance of familiarizing future primary school teachers with the above philosophical approaches in understanding the essence and content of self-improvement of the person is emphasized.

Key words: professional and pedagogical self-improvement, idealistic, materialistic, dialectical, primary school teacher.

Вступ / Introduction. Значення самовдосконалення вчителя початкових класів і для його успішної реалізації в професії, і для постійного особистісно-професійного зростання важко перебільшити. Не менш важливим воно е і для забезпечення високої якості освітнього процесу в початковій школі. Не дарма в сучасному професійному стандарті вчителя початкової школи однією 3 провідних трудових функцій прописана «рефлексія та професійний саморозвиток», що стає нормативною для вчителя кваліфікаційного рівня «бакалавр». Для успішної реалізації цієї трудової функції у кожного учителя складається свое розуміння сутності і змісту власного самовдосконалення, що формуеться як під впливом нормативно заданих зразків, так і на основі 
світоглядних позицій, що певною мірою відображають існуючі фрілософрські погляди на це не просте явище.

Феномен самовдосконалення особистості в науковій думці пов'язуеться із розв'язанням проблеми суб'єктної сутності людини як архітектора власного життя і діяльності, який ініціативно й відповідально організовуе себе, обирае стратегію і тактику свого життевого шляху. Дана багатогранна проблема постае як міждисциплінарна, що традиційно вивчаеться в межах філософського та психолого-педагогічного знання і характеризуеться різноманітністю підходів та варіативністю її вирішення.

Питання самовдосконалення особистості тією чи іншою мірою торкались майже усі філософимислителі минулого і сьогодення, проте найбільш прицільного висвітлення дана проблема набула в фрілософських працях М.Бахтіна, М.Бердяева, В.Біблера, І.Донцова, С.Рубінштейна та багатьох інших. Психологічні аспекти даної проблематики висвітлені в роботах Г.Балла, І.Беха, А.Маслоу, Ю.Орлова, К.Роджерса, Л.Рувинського, В.Франкла та ін.

Ірунтовний аналіз усього розмаїття існуючих в історії філософрії поглядів на саморозвиток, самовдосконалення людини представлений в роботах В.Степанової, В.Тертичної, А.Оплетіна. Одразу ж зазначимо, що в філософській думці звичайним е синонімічне вживання термінів «самовдосконалення» i «саморозвитокм 3 переважним використанням останнього у його взаємозв’язку із «розвитком». Проте, досліджуючи самовдосконалення особистості в культурологічному аспекті, де воно постае як проекція конкретно-історичного духовного поля на особистість, В.Лозовий розглядае самовдосконалення як «основну форму особистісного саморозвитку", для якого значущою е не міра розвитку будь-яких якостей особистості, а їхній моральний зміст, здатність до утворення загальнолюдських моральних цінностей» (Лозовий В., 1991). Самовдосконалення як найвища форма усвідомленого саморозвитку особистості досліджуеться Н.Макарцем, В.Тертичною.

Різним аспектам профресійного самовдосконалення вчителя присвячені дисертаційні дослідження Л.Сущенко, І.Скляренко, О.Прокопової, Т.Шестакової та ін. Проте питання взаемозв'язку філософрського бачення самовдосконалення особистості і його відображення в свідомості учителів і в їх практичній роботі над собою не піднімалось взагалі.

Мета та завдання / Aims and Tasks. Нині простежуеться значна відірваність глибоко філософського знання від практики реального педагогічного буття, де самовдосконалення вчителя часто зводиться до елементарної професійної самоосвіти. Причину цього ми вбачаємо в недостатній філософській осмисленості феномена самовдосконалення вчителями початкових класів та їхніми керівниками. Струнка і зрозуміла фрілософська позиція завжди е дуже практичною, дієвою i стимулюе до адекватних їй дій. Необхідно розширювати розуміння педагогами явища і сутності самовдосконалення особистості з урахуванням сучасних філософських тлумачень даного феномена з метою формування у вчителів початкових класів відповідної світоглядної позиції щодо власного професійного зростання. А для цього треба дослідити основні філософські тенденції до розуміння самовдосконалення особистості, що й стало метою нашої роботи.

Дана мета реалізуеться в ряді завдань:

- проаналізувати розвиток ідеї самовдосконалення особистості в історії філософськкої думки;

- виділити основні підходи в розумінні самовдосконалення;

- порівняти виділені підходи та простежити їх вплив на формування власної світоглядної позиції щодо професійного самовдосконалення у вчителів початкових класів.

Методи / Methods. В ході вивчення й узагальнення наукової літератури з питань дослідження нами використовувались методи аналізу, синтезу, порівняння, узагальнення, феноменологічний та ін. для вирішення поставлених завдань і досягнення окресленої мети науково-теоретичного пошуку.

Результати / Results. Філософія, що за висловом І.Канта «покликана сприяти інтелектуальному i моральному самовдосконаленню людини», розглядає даний феномен в контексті питань сенсу життя особистості, способу іï буття та визначае самовдосконалення виключною здатністю людини і основним призначенням її життя. Основні фрілософрські підходи до саморозвитку особистості, як стверджуе В. Степанова, «зводяться до самовдосконалення людини 3 метою уподібнитися Богові через одкровення; духовно-творчої діяльності сходження до «КращогоЯ»; реалізації себе через діяльнісну взаемодію з іншими; творчого пошуку смислу і пошуку вічності» (Степанова В., 2003).

Ідея самовдосконалення зароджуеться із усвідомленням людиною себе, із виділенням себе із навколишнього середовища, в результаті чого формуються елементи їі самосвідомості, відбувається пошук рушійних сил їі розвитку в самій особистості. Самовдосконалення осмислюеться як шлях здобуття людиною певної міри свободи, незалежності від впливу зовнішнього світу і власних пристрастей, досягнення гармонії з собою, моральної та розумової досконалості. Поширюються 
цінності самопізнання, самовизначення, свідомого самообмеження, самодисципліни (Конфуцій, Сократ, Платон, Аристотель, Епікур та ін). Ідеалом стає людина, яка «робить себе сама шляхом власних зусиль», стаючи «мірою усіх речей» (Горбачев В., 1998).

Подальший розвиток теорії самовдосконалення характеризується появою ідеалістичного та матеріалістичного бачення самовдосконалення 3 акцентом на одному 3 двох нерозривних напрямків самовдосконалення: вдосконаленні свого внутрішнього світу, що відображае особистісну оріентацію самовдосконалення, і вдосконаленні своїх творчих проявів, що е свідченням суспільної орієнтації самовдосконалення. Філософське осмислення самовдосконалення, як зазначає В. Степанова, залежить від виділення двох основ буття людини: укорінення її у вічному, духовнолу бутті чи в тимчасовому, матеріальному. «В цьому контексті «самовиховання» набувае відтінку примушення себе заради інтересів суспільства, що пов'язано з «матеріальнил», і «саморозвиток» як створення свого образа, як пробудження людського в людині - з «ідеальнил» в розумінні духовного» (Степанова В., 2003).

Більше того, як свідчить проведений теоретичний аналіз, «у філософрській думщі формуеться ідеалістичне, матеріалістичне та діалектичне бачення руху людини до вершин досконалості. Ідеалістичне розуміння базуеться на визнанні самоцінності самовдосконалення особистості як суто внутрішньої активності, спрямованої на розвиток духовності, збагачення внутрішнього світу

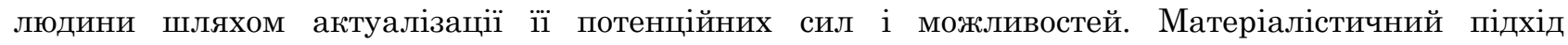
характеризуе самовдосконалення як переважно зовнішню активність особи, спрямовану на досягнення суспільно заданого й соціально обумовленого ідеалу розумової, фізичної та моральної досконалості шляхом корекції власної діяльності та поведінки відповідно до норм і цінностей певного суспільства 3 метою самоутвердження в ньому та забезпечення гарного сьогочасного існування. У діалектичному підході гармонізуються ідеалістичні й матеріалістичні погляди на природу даного феномена на засадах едності протилежностей і пріоритетності гуманістичних цінностей, відповідно до чого самовдосконалення особистості тлумачиться як активність, спрямована і на збагачення внутрішнього світу, і на вдосконалення зовнішніх проявів людини» (Шестакова Т., 2006).

Ідеалістичне розуміння самовдосконалення, що складаеться під впливом Східних філософських течій, Середньовічного теоцентризму передбачае зосередження людини на

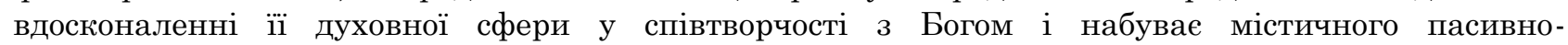
споглядального характеру, здійснюючись шляхом різноманітних духовних практик заглиблення у власний внутрішній світ, аскетизму, підкорення тіла душі за умови відходу від суети світу і носить певною мірою індивідуалістичний характер, яскраво відображений в Християнській ідеї спасіння.

Філософські течії екзистенціалізму (А.Камю, С.Кьеркегор, Ж.Сартр, К.Ясперс, М.Хайдегер та ін.), що стверджуе «чисту самосвідомість», «свободу волі», відповідальність людини і постійну незавершеність ії розвитку; персоналізму (М.Бердяєв, В.Іванов, Н.Лосський, В.Штерн та ін.), що проголошуе особистість духовним першоелементом буття, активним суб’єктом, що здатен творчо мислити i активно діяти, наближаючись до світу високих цінностей, смислів і вищого блага; неотомізму (Е.Жильсон, Ж.Марітен, що визнае закладене від народження духовне начало в людині; феноменології (Ф.Бретано, Е.Гуссерль) з їі ідеєю “трансцендентального суб’екта» та ін. абсолютизують внутрішне «Я» особистості, визначають детермінованість іï індивідуального буття і розвитку виключно внутрішніми мотивами і передумовами (нехтуючи впливом соціального середовища) і в такий спосіб відображають ідеалістичний зміст теорій самовдосконалення.

Категорія буття, запропонована екзистенціоналістами (С.Джурару, Ю.Джендлін, Л.Бінгсвангер, Р.Мей, І.Ялом та ін.) зміщуе акцент із впливу на зовнішній світ (3 інструментальності) на розкриття і здійснення самого себе, але не в смислі розгортання, як моменту найвищого Абсолюту, не в смислі убачання себе в світі, тобто нав'язування світові, а в смислі здійснення себе як самоцінності у загальному прагненні до саморозкриття і саморозвитку. Визнання екзистенції кожного індивіда найбільш важливою його сутністю, проголошення цінності «Я» яким би воно не було, розуміння розвитку самосвідомості як ціннісного переживання свого «Я», а не рефрлексивного бачення себе актуалізуе розуміння самовдосконалення як чистого самопізнання, незалежного від зовнішнього світу саморозвитку (Г.Кнеллер), джерела якого містяться в самій людині і обумовлені суто їі генетичною програмою, а отже не підвладні раціональному поясненню і формуванню. Базуючись на твердженні, що «всі люди добрі, і мають прагнення до досконалості» (К.Роджерс), в основі людини лежить прагнення до позитивних змін, феноленологічний підхід до людини підкреслюе ії здатність до конструктивного самотворення, саморуху в напрямку до незалежності, соціальної відповідальності, креативності, зрілості, повноцінного функціонування.

Розвиваються ідеї морального самовдосконалення: людині пропонується відійти від пригніченого почуття рабства і негараздів суспільства і заглибитись у саму себе, в світ своїх 
особистих переживань шляхом самоспоглядання, глибокого розмірковування над життям і собою, читання гарних книжок, ведення щоденника, стриманого способу життя (етичний індивідуалізм: Р.У.Емерсон, І.В.Гете, Шлейермехер та ін.)

При ідеалістичному розумінні самовдосконалення домінуе спрямованість самовдосконалення на посилення внутрішньої активності, внутрішньої саморегуляції, роботи над собою за умови відірваності від проблем зовнішнього світу, відмови від своїх бажань, прагнень тощо, що відобразилось в Християнській ідеї власного спасіння, в східній філософії в «концепції недіяння» (китайський даосизм), в «концепції мокши» (індійські системи), а також в скептицизмі, стоїцизмі, епікурействі та інших вченнях. Так, Сенека, наприклад, учив своїх послідовників протистояти впливові зовнішнього світу і зосередити усі свої зусилля на самовдосконаленні. Плотін шлях до досконалості бачив у зреченні від усього земного і навіть від «бренної» своеї оболонки - тіла.

В ідеалістичному розумінні самовдосконалення осмислюеться як суто внутрішне життя, часто протиставляючись практичній суспільно корисній діяльності; самозреченість зовнішнього світу за умови посилення внутрішньої активності шляхом самозаглиблення, самоспоглядання, самозосередження покладаються в основу Йоги та інших східних психотехнік. Закликаючи людину змінити перш за все не зовнішній світ, а саму себе - через молитву і працю, через самообмеження своїх потреб, Християнство ставить їй за мету стати досконалою як Отець наш Небесний.

Матеріалістичне бачення самовдосконалення, складаючись під впливом античних ідеалів освіченості та фізичної досконалості, ідей титанізму (величі і всемогутності людини), універсалізму («всебічного розвитку нею своїх сутнісних сил та творчих здібностей») (Горбачев В., 1998) (Відродження і Новий Час), соціоцентризму (примат суспільства над особистістю) базуеться на ствердженні пріоритетів розумового розвитку людини та прояву іiі активної життевої позиції, зовнішньої перетворюючої активності над внутрішньою, відповідно до чого формуеться ії раціонально-дійова настанова на самореалізацію, а дії по самозміні набувають функціонального, самостверджуючого характеру (Тертична В., 1999).

В умовах посилення соціоцентризму, матеріалістичного бачення світу та ствердження примату суспільства над людиною їі зовнішня перетворююча активність превалюе над внутрішньою, а в роботі над собою людина оріентуеться на підкорення індивідуального суспільному. Самовдосконалення як соціальний процес базуеться на вимогах суспільства до особистості, розвиваються «діяльно-забезпечуюча природа самотворення» та «адаптивне і наслідувальне начала в самореалізації, а «невиразність індивідуальних характеристик у програмах самореалізації значної маси населення компенсуеться зразками поведінки, які культивуються керуючою ідеологією політичних систем» (Тертична В., 1999). Прояви активності обмежуються суспільно-корисною сферою діяльності, а суб’ектна основа розвитку - присвоєнням соціальних цінностей.

В цілому ж самовдосконалення особистості втрачає свої пріоритетні позиції порівняно із зовнішньою перетворюючою діяльністю i починає розглядатись як допоміжна, службова активність, одна з умов творчості людини.

Матеріалістичне бачення самовдосконалення посилюеться із розвитком раціоналістичного антропоцентризму Нового Часу, при якому людина розглядаеться як «розумний і вправний робітник у величезній майстерні природи, «творець нового світу і краси в ньому», як людино-бог,

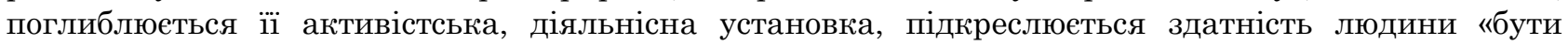
господарем власної долі і творцем свого щастя».

В результаті ствердження культу розуму, краси тіла й думки людини, цінності їі творчої діяльності (що з'являеться і в часи Античності i в період Відродження, Нового Часу) самовдосконалення починае розглядатись як шлях досягнення величі і всемогутності людини, «всебічного розвитку нею власних сутнісних сил і творчих здібностей» (Горбачев В., 1998), посилюеться активістська, діяльнісна установка людини, підкреслюеться здатність людини «бути господарем власної долі і творцем свого щастя».

Дещо іншого вигляду набувае ця ідея в контексті екзистенціоналізму, персоналізму, де проголошуеться цінність людського Я яким би воно не було (проявилась увага до внутрішнього світу людини, але не з метою його вдосконалення, а прояву в діяльності, адже людина має право на вільний активний прояв себе, при чому не акцентуеться увага на врахуванні певних духовноморальних цінностей, основ)

Спроби поєднання цих двох напрямків простежуються ще в етнокультурі Київської Русі в ідеях «діючої любові», служіння людям, де самовдосконалення виявляеться одночасно і духовно, i соціально спрямованим, і зовнішньо, і внутрішньо активним процесом і розуміеться як «особлива життева позиція, що переводить внутрішне знання про добро в практичну іпостась» (Тертична В., 1999). Насичуючись в «етичної філософії» (О.Радіщев, О.Бестужев, О.Куніцин та ін.), та «рілософії серця» (Г.Сковорода) ідеями едності почуттевого i раціонального начал в людині, 
самовдосконалення, на думку Г.Сковороди, здійснюеться шляхом самопізнання людиною «серцевих» глибин власного «Я» та їх реалізації в «спорідненій» діяльності (Тертична В., 1999).

Діалектика класичної німецької філософії знімае протиставлення світу ідеалів та світу реальних цінностей, духовного та розумового розвитку, зовнішньої перетворюючої діяльності та роботи над собою. Ідеалом самовдосконалення постає людина, якій притаманні «сила мислення як світло пізнання, сила волі як енергія характеру, сила почуття як любов» (Л.Фейербах), що стають

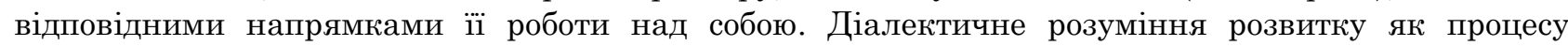
саморуху з притаманними йому внутрішніми законами (Г.Гегель) підсилює ролі свободи і творчості людини в ньому і породжуе розуміння шляхів самовдосконалення особистості у самообмеженні у власному егоїзмі, еднанні зі світом («рілософрія тотожності» Ф.Шеллінг), самозреченні в ім’я іншого («релігія любові» Л.Фейербах), слідуванні обов’язку (І.Кант) та ін.

Врівноваження гуманістичних та раціоналістичних підходів до розуміння людини та ії самовдосконалення на засадах розвитку духовності, поглиблення самосвідомості й активізації творчості з метою досягнення ідеалу «надлюдини» (В.С.Соловйов) стае характерним для Російської релігійної фрілософії (М.М.Бахтін, М.О.Бердяев, В.С.Соловйов, П.О.Флоренський, С.Л.Франк, Л.Шестов та ін.). Самовдосконалення людини визнаеться сенсом життя і полягае в рухові особистості до свого «Я», що е місцем зустрічі, зосередження найвищих цінностей особистості. Метою людського існування визнаеться вдосконалення її особистості як активної істоти шляхом завоювання духовності і еднання з Богом у процесі творчості.

Так М.Бердяєв обумовлюе ідею зв'язку творчості і самовдосконалення, підкреслюючи їх нерозривність та взаємовплив. Розуміння духовності і як висхідного од Бога, і як людської сутності призводить до осмислення самовдосконалення як досягнення якісно іншого рівня душевного життя підтримання і розвитку в людині здатності доторкнутися до перевершуючи її нетлінних цінностей любові, мудрості, істини, добра, краси і жити, керуючись ними. I відповідно поняття «салосвідолість» трактуеться російськими фрілософрами вже не як «саморефрлексія», а як пробудження «знати не себе, а істину, бажати не себе, а добра», як здатність виносити моральну оцінку самому собі, тобто як совість (П.Д.Юркевич). як здатність особистісного «Я» транцендувати себе до метафізичних глибин буття, переживаючи себе як частину життя Абсолюту, як «повне знаходження свого розкритого «Я» у свідомості», як «самооцінка особи згідно із надособовими ідеями, що накопичуються у свідомості, й активне їі (особи) перетворення згідно з цими ідеями» (Гершензон). Російські філософи наголошують, що наслідком самовдосконалення, в основі якого лежить еднання людини зі світом (а не протиставлення), розкриття в ній того «Я», яке $\epsilon$ «зосередженням світового цілого» (С.Франк), буде не лише покращення особистості, а й світу навколо неї.

Проблема виживання й подальшого існування людської цивілізації, висвітлена значними суспільними та екологічними катастрофами сучасності, підкреслюе значення самовдосконалення особистості як основного способу досягнення позитивних змін в оточуючому середовищі. Так видатні мислителі й суспільні діячі XX ст. (В.Вернадський, А.Сорокін, А.Швейцар, теоретики Римського клубу) висловлюють переконання, що порятунок людства можливий лише за рахунок «Людської революції» шляхом «якісної зміни процесів саморозвитку окремої людини і всього людства, їхне підпорядкування глобальним моральним імперативам» (Тертична В., 1999). Започаткування «нового гуманізму» (Печчеї), покликаного «забезпечити трансформацію людини $\mathrm{i}$ відновити тим самим культурну еволюцію людського роду» (Горбачев В., 1998), актуалізувало духовно-моральні основи самотворення особистості.

Виокремлення гуманістичного підходу до вивчення антропологічних категорій у самостійний напрямок з середини XX ст. (А.Маслоу, К.Роджерс, В.Франкл та ін.) сприяе поєднанню матеріалістичних та ідеалістичних поглядів на проблему самовдосконалення особистості та

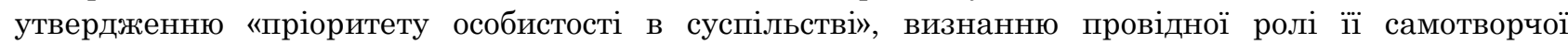
активності в процесі особистісного і суспільного зростання, розгляду вдосконалення особистості і суспільства як процесів, що взаємно стимулюють один одного. Підкреслюеться зв'язок самовдосконалення і творчості, їх взаємовплив і взаємообумовленість.

Як бачимо, філософське осмислення самовдосконалення людини протягом тривалої історії розвитку суспільства суттево змінювалося від яскраво ідеалістичних до загострено матеріалістичних поглядів і в сучасній філософській думці зрештою врівноважуеться на діалектичних засадах його світоглядного розуміння. Здійснена нами спроба порівняльної характеристики зазначених фрілософоських поглядів представлена в табл. 1. 
Таблиия 1

Порівняльна характеристика ідеалістичного, матеріалістичного та діалектичного розуміння самовдосконалення особистості

\begin{tabular}{|c|c|c|c|}
\hline Розуміння & Ідеалістичне & Матеріалістичне & Діалектичне \\
\hline \multirow[t]{3}{*}{$\begin{array}{l}\text { Світоглядна } \\
\text { основа }\end{array}$} & $\begin{array}{l}\text { Базуеться на усвідомленні } \\
\text { надприродного начала та } \\
\text { абсолютизації його ролі } \\
\text { самовдосконаленні людини }\end{array}$ & $\begin{array}{l}\text { Базуеться на запереченні } \\
\text { надприродного начала та } \\
\text { на абсолютизації } \\
\text { млажливих } \\
\text { самовдосконй } \\
\text { (переважноно продесійного) }\end{array}$ & 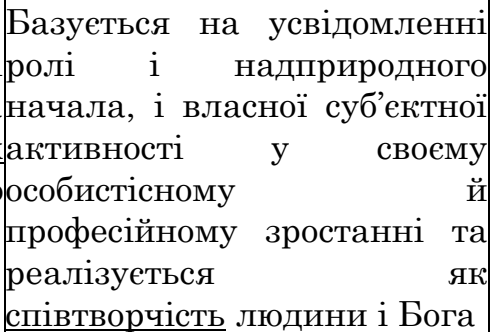 \\
\hline & $\begin{array}{l}\text { Пріоритетність духовно- } \\
\text { моральних цінностей }\end{array}$ & $\begin{array}{l}\text { Пріоритетність утилітарно- } \\
\text { Прагматичних цінностей }\end{array}$ & $\begin{array}{l}\text { Пріоритетність } \\
\text { гуманістичних цінностей }\end{array}$ \\
\hline & $\begin{array}{|lr|}\text { Установка на } & \text { вільне } \\
\text { самовираження } & \text { й } \\
\text { саморозвиток } & \\
\end{array}$ & \begin{tabular}{|lrr} 
Установка & на \\
самоутвердження & в & світі, \\
суспільстві & & \\
\end{tabular} & $\begin{array}{l}\text { Установка на тво } \\
\text { самореалізацію в світі }\end{array}$ \\
\hline Сутність & $\begin{array}{l}\text { Рух до Божественного } \\
\text { ідеалу, до повноти прояву } \\
\text { людської сутності }\end{array}$ & $\begin{array}{l}\text { Рух до суспільно заданого і } \\
\text { соціально обумовленого } \\
\text { iдеалу }\end{array}$ & $\begin{array}{l}\text { Рух до ідеалу «надлюдини } \\
\text { до акмевершин її розвитку }\end{array}$ \\
\hline \multirow[t]{2}{*}{ Мета } & $\begin{array}{l}\text { Здійснюеться } 3 \text { метою } \\
\text { підготовки до життя вічного } \\
\text { й забезпечення якомога } \\
\text { більш повного особистісного } \\
\text { існування }\end{array}$ & 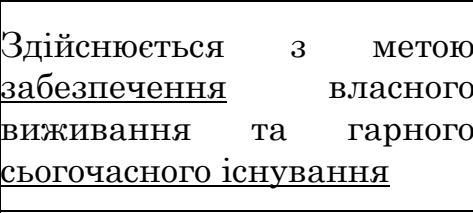 & $\begin{array}{l}\text { Здійснюеться } \\
\text { особистісного зростання } \\
\text { вдосконалення сьогочасно } \\
\text { існування себе та інших }\end{array}$ \\
\hline & $\begin{array}{l}\text { Заради } \\
\text { спасіння й розвитку }\end{array}$ & $\begin{array}{l}\text { Заради } \quad \text { індивідуального } \\
\text { життя в суспільстві }\end{array}$ & $\begin{array}{l}\text { Заради життя й спасін } \\
\text { багатьох } \\
\end{array}$ \\
\hline \multirow[t]{2}{*}{ Зміст } & \begin{tabular}{|l|} 
Спрямовується на розвиток \\
Духовності, \\
внутрішнього світу люагачення \\
\end{tabular} & 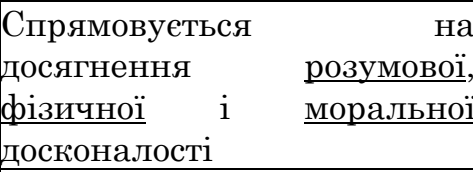 & 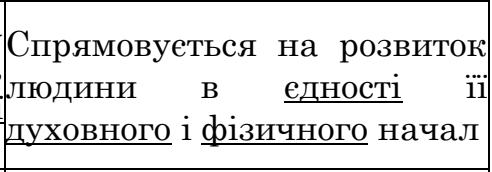 \\
\hline & $\begin{array}{l}\text { Зосереджується } \\
\text { вдосконаленні, збагаченні } \\
\text { внутрішнього світу } \\
\text { обов'язково проявиться і у } \\
\text { зовнішньому) }\end{array}$ & $\begin{array}{l}\text { Зосереджується } r \text { на } \\
\text { вдосконаленні } \\
\text { проявів (що е вираженнням } \\
\text { внутрішньої сутності), в т.ч. } \\
\text { на корекції поведінки, } \\
\text { розвитку майстерності. }\end{array}$ & $\begin{array}{l}\text { Врівноваження } \\
\text { внутрішнього } \\
\text { вдосконалення } \\
\text { проявів. }\end{array}$ \\
\hline Механізми & $\begin{array}{l}\text { Діє на розвиток через } \\
\text { Психічне }\end{array}$ & \begin{tabular}{|l} 
Діє на розвиток \\
фрізичне
\end{tabular} & $\begin{array}{l}\text { Діє на розвиток через } \\
\text { поєднання } \\
\text { психічного. }\end{array}$ \\
\hline \multirow[t]{2}{*}{ Форми } & $\begin{array}{|lc|}\text { Реалізуеться } & \text { переважно у } \\
\text { вигляді } & \text { внутрішньої } \\
\text { активності } & \\
\end{array}$ & $\begin{array}{l}\text { Реалізуеться } \quad \text { у } \\
\text { проявлених фрормах }\end{array}$ & \begin{tabular}{|llr|} 
Реалізуеться & \multicolumn{1}{c}{ як } & у \\
внутрішньо-, так і в & зовні \\
проявлених фрормах & & \\
\end{tabular} \\
\hline & $\begin{array}{l}\text { Основними } \\
\text { пізнання й йами } \\
\text { власної глибинної сутності }\end{array}$ & $\begin{array}{l}\text { Основними доромами } \epsilon \\
\text { самоосвіта і самовиховання }\end{array}$ & 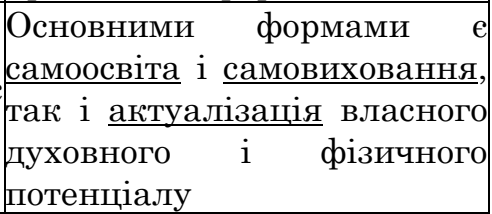 \\
\hline Методи & $\begin{array}{l}\text { Основними методами } \\
\text { пізнання Істини в } \\
\text { світі або жобі і } \\
\text { самовираження }\end{array}$ & $\begin{array}{l}\text { Основними методами } \\
\text { самопізнання } \\
\text { саморегуляція як пізнання } \\
\text { і регуляція власної самості } \\
\text { відповідно до власних } \\
\text { щінностей і пріоритетів }\end{array}$ & 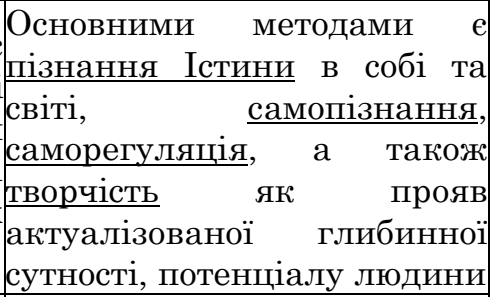 \\
\hline Прийоми & 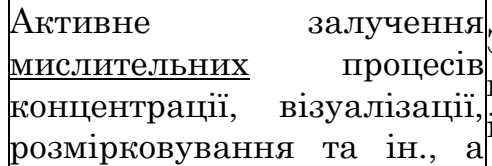 & 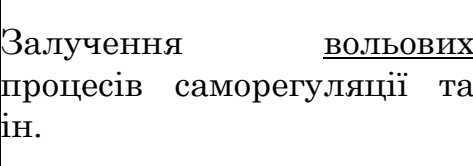 & $\begin{array}{l}\text { Використання } \\
\text { мислительних і вольових } \\
\text { процесів, а також активне } \\
\text { залучення }\end{array}$ \\
\hline
\end{tabular}




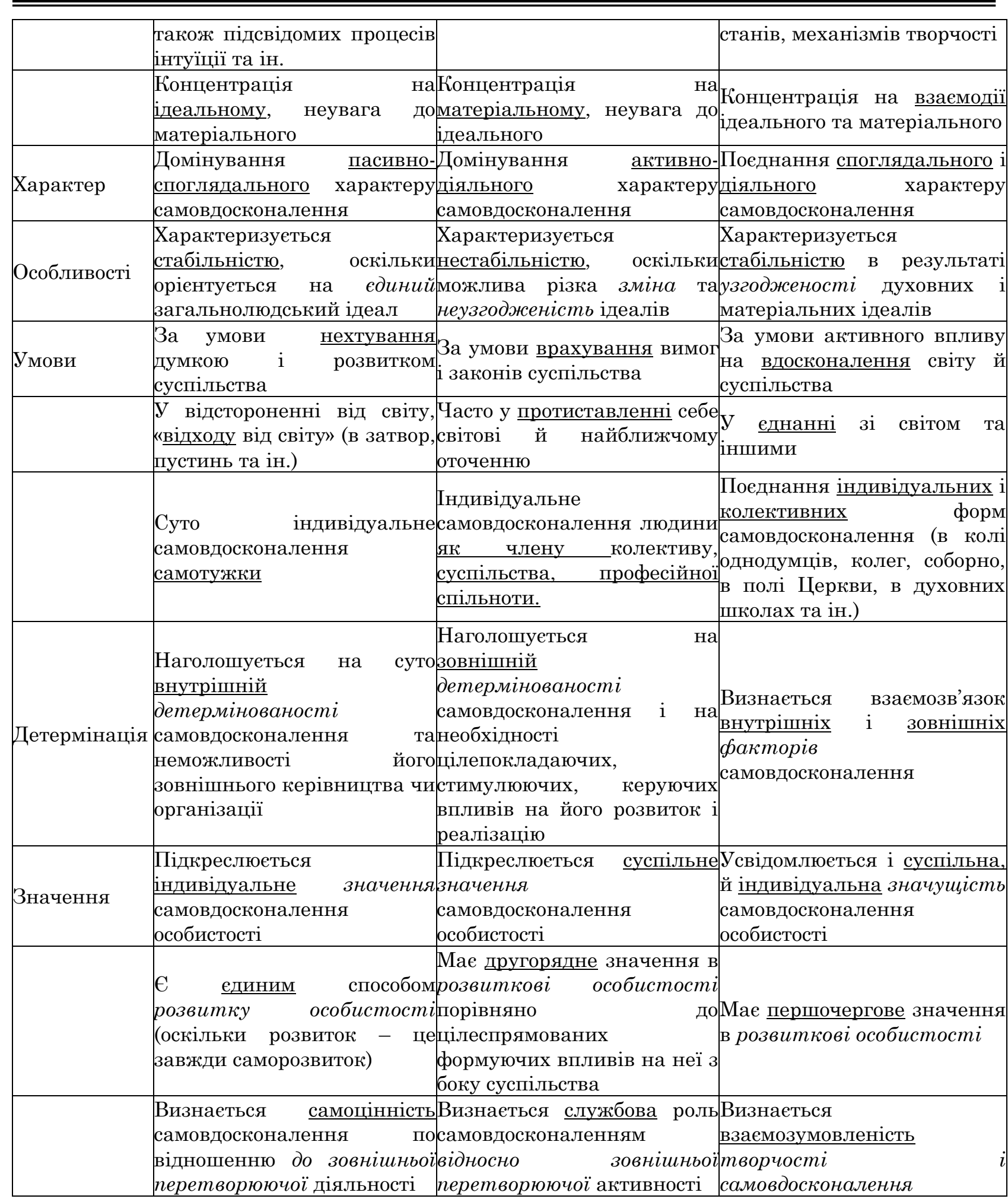

Таке фрілософське осмислення френомена самовдосконалення не лише фріксується в теорії фрілософської думки, а й відображається в свідомості і практиці життя кожного окремого учителя залежно від його індивідуальних пріоритетів, цінностей, переконань. Педагог початкової школи формуе власну філософію буття, відповідно до якої вибудовуе свою неповторну стратегію життя, обирає провідну лінію професійної реалізації та реалізує тактику власного професійного зростання. I на чому зробить акцент учитель початкових класів у своєму особистісно-профресійному самовдосконаленні багато в чому залежить від його фрілософської позиції: переважно ідеалістичної, матеріалістичної чи діалектичної. В його щоденній роботі над собою уся ця глибоко фрілософрська теорія перетворюється на абсолютно практичні речі: чому надасть більшої переваги учитель розвитку професійних якостей, здібностей, чи удосконаленню і збагаченню власної професійної діяльності новими знахідками і напрацюваннями педагогічної науки і практики, чи, можливо йому вдасться гармонійно поєднати в своєму самовдосконаленні роботу і над своєю особистістю, i 
над діяльністю.

Обговорення / Discussion. Особливості філософрької позиції кожного учителя початкових класів стосовно власного професійного самовдосконалення відображаються у визначенні сутності й виділенні провідного напряму власного професійного самовдосконалення, у виборі його мети й пріоритетних завдань роботи над собою, й доборі основних методів самовпливу й самотворення.

Так, відповідно до світоглядних пріоритетів можна умовно виділити три групи вчителів початкових класів залежно від їх домінуючих тенденцій у власному професійному самовдосконаленні: педагоги-ідеалісти, педагоги-матеріалісти, педагоги-діалектики.

Базуючись на ідеалістичнолу розумінні самовдосконалення особистості, досить значна частина учителів початкових класів зосереджуе свою увагу в роботі над собою на самовиховних аспектах самотворення, що забезпечують успішну особистісну адаптацію до умов учительської праці і до вимог педагогічної професії за рахунок ефективного розвитку професійно значущих якостей педагога та саморегуляції своєї професійної поведінки й діяльності. Такими учителями усвідомлюеться виключне значення самовдосконалення для власного особистісно-професійного зростання на засадах розвитку духовності, збагачення внутрішнього світу, пріоритетності духовноморальних цінностей, яке спрямовуеться на досягнення ідеалу над-людини (залежно від духовної традиції, в межах якої рухається учитель). Їх професійне самовдосконалення носить особистісно розвивальний характер. Рух від Я-реального до Я-ідеального в професії здійснюеться за рахунок багатопланової діяльності вчителя по самопізнанню, самоаналізу, самооцінці, самоконтролю, самонавіюванню, самонаказу, самопереконанню, самовправлянню, самозвіту, саморегуляції та ін., в ході якої відбувається постійний розвиток своєї особистості як професіонала шляхом систематичного формування професійно значущих рис i якостей та адаптування своїх індивідуально-неповторних особливостей до вимог педагогічної діяльності. Все це допомагає учителеві початкових класів досягти вершин педагогічної майстерності, підвищити загальну i професійну культуру, набути рівня професіоналізму в цій непростій діяльності. Самовдосконалення реалізуеться переважно у вигляді внутрішньої активності, що базуеться на самопізнанні (як пізнанні Істини в собі і світі) та передбачає актуалізацію власної глибинної сутності й вільне самовираження в професії. Частим є активне залучення мислительних процесів концентрації, візуалізації, розмірковування та ін., а також підсвідомих процесів інтуїції та ін. для досягнення успіху в професійній сфері. Самовдосконалення осмислюеться такими вчителями як глибоко особистісний процес, що не потребуе шаблонів, обмежень, стереотипів і директивних наказів, та детермінуеться переважно особистісними чинниками (системою вимог особи до самої себе та усталеними внутрішніми феноменами), а тому здійснюеться виключно індивідуально. Необхідність і напрямок самозміни в професії визначаеться педагогом зсередини як суто особистісна задача внаслідок усвідомлення певної колізії та грунтуеться на власній ініціативі вчителя. Пріоритет надаеться особистісному вектору самовдосконалення, в якому домінують процеси самопізнання, самоаналізу, самокритики, нерідко - самокопання і т.п. Надмірна зосередженість вчителя на своєму внутрішньому світові може призводити до домінування пасивноспоглядального характеру самозмін та формувати певну відстороненість від думки оточуючих, від вимог суспільства і професії до якості власної професійної реалізації. Нерідко проявляеться протиставлення себе іншим, нехтування колективними формами творчого саморозвитку педагогів, дещо зневажливе ставлення до різноманітних творчих проектів, конкурсів і навіть до взаємодопомоги, взаємопідтримки з боку колег. Такі вчителі рідко відгукуються на пропозицію взяти участь у профресійних творчих конкурсах, бо “їм не потрібна слава», вони більше працюють над собою, ніж над удосконаленням навчально-виховного процесу. В цілому ж самовдосконалення учителями-ідеалістали усвідомлюеться як особистісно значущий і внутрішньо детермінований процес досягнення позитивних особистісних змін відповідно до самостійно визначеної концепції власного професійного зростання.

Переважна більшість учителів початкових класів, базуючись на матеріалістичнолу розумінні профресійного самовдосконалення особистості, розглядають його як допоміжний напрямок професійної діяльності, що має діяльнісно-забезпечувальний характер і спрямовуеться на підвищення ефективності навчально-виховного процесу, досягнення високої якості педагогічної праці, шляхом переважно самоосвітніх дій по збагаченню педагогічної діяльності новими розробками в галузі педагогічної теорії та практики. Акцентуючи на функціональному аспекті самовдосконалення такі учителі надають дещо другорядного значення своєму особистісному розвиткові як професіонала, повністю зосереджуючись на підвищенні якості навчального процесу. Їхне самовдосконалення нерідко ототожнюеться 3 професійною самоосвітою, спрямованою на підвищення професійної компетентності, на розширення й поглиблення професійного світогляду, на пошук нових ідей, способів і прийомів роботи, на творче вивчення досвіду інших, а також на аналіз і узагальнення власного досвіду й творче вирішення професійно-педагогічних задач. 
Завдяки самоосвіті педагог реалізовуе власні пізнавальні інтереси та потреби, розвиває інтелектуальні та особистісні якості. Проте самовдосконалення таких учителів часто базуеться на пріоритетності утилітарно-прагматичних цінностей, основний вектор руху від Я-реального до Яідеального проходить в межах соціально заданих вимог до особистості і професійної діяльності вчителя початкових класів та детермінуеться переважно протиріччям між вимогами професії та наявними здібностями і можливостями педагога, його індивідуальним стилем діяльності i спілкування, досвідом роботи. Їхне самовдосконалення зазвичай обумовлюється нормативними еталонами суспільства і професії щодо особистості педагога, реалізуеться переважно в межах навчально-методичної роботи та певною мірою залежить від рівня керівництва цим процесом, взаємної вимогливості й взаемодії у педагогічному колективі. Вагомим стимулом у роботі педагога над собою стае праця в колективі однодумців, спільна творчість учителів, їх взаємодопомога у справі підвищення педагогічної майстерності кожного. Надмірне зосередження на зовнішніх вимогах до вчителя нерідко призводить до того, що такі педагоги-прагматики набагато менше приділяють уваги внутрішній роботі над собою, але насичують свою роботу різноманітними зовнішніми атрибутами, інструментаріем. Вони 3 радістю демонструють результати своїх педагогічних пошуків, показуючи які вони «майстрині», бо «стільки ж усього понамальовували й понавирізали», скільки наочності зробили, а от майстерності педагогічного впливу, тонкості педагогічної взаемодії часто так і не досягли. В цілому ж професійне самовдосконалення педагогами-латеріалістали усвідомлюеться як суспільно значуще й зовнішньо детерміноване явище. Провідними цільовими орієнтирами професійного самовдосконалення педагога стають досягнення ефективного рольового статусу в навчально-виховній взаємодії та забезпечення успішного функціонування в професії. Реалізація цих завдань значною мірою обумовлюеться такими соціальними факторами як нормативність суспільних вимог до вчителя та його діяльності, зовнішня організація і керівництво з боку усіх управлінських структур освіти самовдосконаленням кожного педагога.

Лише незначна частина учителів початкових класів, базуючись на діалектичному розумінні професійного самовдосконалення особистості, вбачають в ньому головний шлях професійного зростання й ефективної самореалізації в професії та реалізують його в едності пізнавальних $\mathrm{i}$ творчих, самопізнавальних $\mathrm{i}$ самотворчих процесів в ході самоосвіти, самовиховання й самоактуалізації, що виступають основними формами самовдосконалення пеагога. Творчість покладається в основу самовдосконалення педагога, яке спрямовується на актуалізацію власного творчого потенціалу педагога в професії, на становлення учителя початкових класів як суб’єкта професійного розвитку, на досягнення ним акме-вершин особистісного і професійного зростання. Творча дослідницька діяльність, в якій народжуеться й реалізуеться творча індивідуальність педагога, в якій відбувається творче самовираження вчителя початкових класів i, разом з тим, його професійне зростання, стає основним механізмом самоактуалізації педагога як провідної форми його професійного самовдосконалення. Ще В.Сухомлинський казав, що стає майстром педагогічної праці найшвидше той, хто відчув у собі дослідника. Такі вчителі свідомо вибудовують і реалізують власну тактику і стратегію свого професійного розвитку-саморозвитку (від самовизначення до творчої самореалізації) напротивагу домінуючій у педагогічній сфері моделі адаптивної поведінки й простого функціонування в професії. Це «зірочки». Їх мало. Але саме вони задають основний тон професійних самозмін в колективі і суспільстві, надихають інших до творчого самовдосконалення в професії. Вони з радістю діляться напрацюваннями, дуже часто й конструктивно взаємодіють в педагогічних колективах з однодумцями, спрямовуючи свої творчі зусилля на вирішення актуальних проблем педагогічного сьогодення, на побудову нових векторів розвитку педагогічної науки і практики. Такі учителі рівномірно піклуються і про внутрішню роботу над собою, і про якість своеї зовнішньої проявленості в професії, коректно поєдують самоосвітній і самовиховний напрямки роботи над собою, самоформуючі й самоактуалізуючі впливи на себе, виступаючи справжніми педагогами-гармонізаторами в професії. В траєкторії руху педагога до досконалості додається ще один вектор - від Я-потенційного до Я-актуального, що засвідчуе охоплення самовдосконалюючими впливами й найбільш глибоких підструктур, таких як творчий потенціал, сутність, ціннісно-смислове ядро особистості, які, відповідно до їх сутнісної специфіки, потребують не лише формуючого, а й актуалізуючого впливу на власний розвиток. Професійне самовдосконалення педагога реалізуеться за умови едності зовнішніх чинників та внутрішніх передумов, які відіграють ключову роль у самовдосконаленні вчителя, що спрямовуеться на вироблення власного педагогічного стилю, на самовираження своєї творчої індивідуальності, а не лише на продуктивне виконання педагогічної діяльності. В цілому ж самовдосконалення педагогами-діалектикали усвідомлюеться як творчий особистісно і суспільно значущий процес якісних самозмін, детермінованих як внутрішніми, так і зовнішніми чинниками, що забезпечуе досягнення педагогом акме-вершин особистісного і професійного розвитку та максимального 
розкриття власного потенціалу в професії, а тому здійснюеться не лише в формі самоосвіти й самовиховання, а й самоактуалізації.

Для врівноваження ідеалістичних та матеріалістичних тенденцій в роботі вчителя над собою і для виведення більшості педагогів початкових класів до діалектичного розуміння власного професійного самовдосконалення корисним було 6 їх ознайомлення 3 представленими вище фрілософськими підходами в розумінні сутності і змісту самовдосконалення особистості.

Висновки / Conclusions. В ході проведеного теоретичного дослідження нами було виділено й охарактеризовано основні підходи до розуміння самовдосконалення людини, що склались в історії філософської думки. Виявлено, що самовдосконалення особистості відбуваеться в двох напрямках: вдосконалення свого внутрішнього світу, що відображае особистісну оріентацію самовдосконалення, і вдосконалення своїх зовнішніх проявів, що є свідченням суспільної орієнтації самовдосконалення. Співвідношення цих двох напрямків самовдосконалення, які, в той же час, можна розглядати і як його основні способи, не залишилось незмінним. Тривалий час домінувала спрямованість самовдосконалення на посилення внутрішньої самоактивності за умови відірваності від проблем зовнішнього світу, відмови від своїх бажань, прагнень і т.п., що відобразилось в Християнській ідеї власного «спасіння», в східних концепціях «недіяння» та інших філософських вченнях. Дана тенденція була різко змінена орієнтацією особистісного самовдосконалення на суспільний прогрес, на професійну самореалізацію, що широко впроваджувалась за часів марксистсько-ленінської ідеології і була визначена ㄲï основними положеннями. Нині підкреслюеться діалектична едність обох напрямків самовдосконалення, що підтверджується сучасними науковими дослідженнями І.Донцова, В.Лозового, С.Барановської та ін.

Представлене виділення серед усіх фрілософрьких трактувань самовдосконалення людини ідеалістичного, матеріалістичного та діалектичного його бачення, на нашу думку, е хоча і досить умовним і суперечним, проте дуже практичним і наочним, а отже і легким для усвідомлення учителями початкових класів і зручним для подальшого використання в ході аналізу світоглядних передумов вироблення власної концепщії професійного самовдосконалення.

Список використаних джерел і літератури:

Гаджиева, Н. М., Никитина, Н. Н., \& Кислинская, Н. В. (1998). Основы салосовершенствования: Тренинг самосознания. Екатеринбург [in Russian].

Горбачев, В. Г. (1998). История фбилософии: Краткий курс лекиий. Брянск [in Russian].

Донцов, И. А. (1975). Личное самосовершенствование и мораль. Москва [in Russian].

Кандыба, В. М. (2003). Мировой опьы духовного саморазвития. Энциклопедия духовной самореализации. Москва [in Russian].

Коваленко, Ю. В. (2002). Субфійська модель моральнісного самовдосконалення (історико-етичний acnект). (Автореф. дис. канд. філос. наук). Київський національний ун-т ім. Тараса Шевченка. Київ [in Ukrainian].

Лозовой, В. А. (1991). Самовоспитание личности как фбилософбско-социологическая проблема. (Автореф. дис. д-ра филос. наук). Институт философии. Киев [in Russian].

Маслоу, А. (1994). Самоактуализаиия личности и образование / пер. с англ., предисл. Г. А. Балла. Киев-Донецк [in Russian].

Степанова, В. Е. (2003). Философбско-методологические основания саморазвития личности. (Автореф. дисс. канд. филос. наук.) Якутский государственный ун-т им. М. К. Амосова. Якутск [in Russian].

Тертична, В. Ф. (1999). Самовдосконалення особистості: культурологічний аспект. (Автореф. дис. канд. філос. наук). Харківський національний ун-т ім. В. Н. Каразіна. Харків [in Ukrainian].

Шестакова, Т. В. (2006). Формування готовності майбутніх учителів до профбесійного самовдосконалення. (Автореф. дис. канд. пед. наук). Інститут вищої освіти Академії педагогічних наук України. Київ [in Ukrainian].

References:

Gadzhieva, N. M., Nikitina, N. N., \& Kislinskaya, N. V. (1998). Osnovy' samosovershenstvovaniya: Trening samosoznaniya [Fundamentals of Self-Improvement: Self-Awareness Training]. Ekaterinburg [in Russian].

Gorbachev, V. G. (1998). Istoriya filosofi: Kratkij kurs lekcii [History of Philosophy: Brief Course of Lectures]. Bryansk [in Russian].

Doncov, I. A. (1975). Lichnoe samosovershenstvovaniye i moral [Personal Cultivation and Morality]. Moscow [in Russian].

Kandy'ba, V. M. (2003). Mirovoj opy't duxounogo samorazvitiya. E'ncy'klopediya duxounoj samorealizacii [World Experience of Spiritual Self-Development. Encyclopedia of Spiritual Self-Realization]. Moscow [in Russian].

Kovalenko, Yu. V. (2002). Sufiiska model moralnisnoho samovdoskonalennia (istoryko-etychnyi aspekt) [Sufi Model of Moral Self-Improvement (Historical and Ethical Aspect)]. (Extended abstract of Candidate's thesis). Kyiv [in Ukrainian].

Lozovoj, V. A. (1991). Samovospitanie lichnosti kak filosofsko-sociologicheskaya problema [Self-Education of Personality as a Philosophical and Sociological Problem]. (Extended abstract of Candidate's thesis). Kyiv [in Russian]. 
Maslou, A. (1994). Samoaktualizaciya lichnosti i obrazovanie [Personality Self-Actualization and Education] I translated and introduction of G. A. Ball. Kiev-Donetsk [in Russian].

Stepanova, V. E. (2003). Filosofsko-metodologicheskie osnovaniya samorazvitiya lichnosti [Philosophical and Methodological Bases of Personality Self-Development]. (Extended abstract of Candidate's thesis). Yakutsk [in Russian].

Tertychna, V. F. (1999). Samovdoskonalennia osobystosti: kulturolohichnyi aspekt [Self-Improvement of the Personality: Cultural Aspect]. (Extended abstract of Candidate's thesis). Kharkiv [in Ukrainian].

Shestakova, T. V. (2006). Formuvannia hotovnosti maibutnikh uchyteliv do profesiinoho samovdoskonalennia [Formation of Future Teachers' Readiness for Professional Self-Improvement]. (Extended abstract of Candidate's thesis). Kyiv [in Ukrainian].

Дата надходження статті: «12» жовтня 2019 р.

Стаття прийнята до друку: «07» листопада 2019 р.

Шестакова Тетяна - доцент кафедри педагогіки і психології Українського гуманітарного інституту, кандидат педагогічних наук, доцент

Shestakova Tetiana - Assistant Professor of the Pedagogy and Psychology Department of Ukrainian Humanities Institute, Candidate of Pedagogical Sciences, Associate Professor

\section{Цитуйте иљю статтю як:}

Шестакова, Т. (2019). Філософрські професійного початкових класів. Педагогічний дискурс, 27, 61-71. doi: 10.31475/ped.dys.2019.27.07.
Cite this article as:

витоки Shestakova, Т. (2019). The Philosophical Origins of Professional Self-Improvement of Primary School Teachers. Pedagogical Discourse, 27, 61-71. doi: 10.31475/ped.dys.2019.27.07. 